\title{
Review \\ Evidence for Ovarian and Testicular Toxicities of Cadmium and Detoxification by Natural Substances
}

\author{
Martin Massányi ${ }^{1}\left(\mathbb{D}\right.$, Soisungwan Satarug ${ }^{2}$, Roberto Madeddu ${ }^{3}$, Robert Stawarz ${ }^{4}$ and Peter Massányi ${ }^{4,5, *(1)}$ \\ 1 AgriBioTech Research Centre, Slovak University of Agriculture in Nitra, Tr. A. Hlinku 2, 94976 Nitra, Slovakia; \\ martinmassanyi@yahoo.com \\ 2 Kidney Disease Research Collaborative, Centre for Health Services Research, Translational Research Institute, \\ Brisbane 4102, Australia; sj.satarug@yahoo.com.au \\ 3 Department of Biomedical Sciences-Histology, University of Sassari, Viale San Pietro 43/B, \\ 07100 Sassari, Italy; rmadeddu@uniss.it \\ 4 Institute of Biology, Pedagogical University of Kraków, ul. Podchorązych 2, 30-084 Krakow, Poland; \\ robert.stawarz@gmail.com \\ 5 Institute of Applied Biology (INABI), Slovak University of Agriculture in Nitra, Tr. A. Hlinku 2, \\ 94976 Nitra, Slovakia \\ * Correspondence: peter.massanyi@uniag.sk
}

check for

updates

Citation: Massányi, M.; Satarug, S.;

Madeddu, R.; Stawarz, R.; Massányi, P. Evidence for Ovarian and

Testicular Toxicities of Cadmium and Detoxification by Natural Substances.

Stresses 2022, 2, 1-16. https://

doi.org/10.3390/stresses2010001

Academic Editors: David R. Wallace, Pinar Uysal Onganer and Aleksandra Buha Đorđević

Received: 19 November 2021

Accepted: 19 December 2021

Published: 22 December 2021

Publisher's Note: MDPI stays neutral with regard to jurisdictional claims in published maps and institutional affiliations.

Copyright: (c) 2021 by the authors. Licensee MDPI, Basel, Switzerland. This article is an open access article distributed under the terms and conditions of the Creative Commons Attribution (CC BY) license (https:// creativecommons.org/licenses/by/ $4.0 /)$.

\begin{abstract}
Cadmium (Cd) is an environmental toxicant, capable of reducing mitochondrial ATP production and promoting the formation of reactive oxygen species (ROS) with resultant oxidative stress conditions. The ovary and testis are the primary gonads in which female gametes (oocytes) and male gametes (spermatozoa), estrogen and testosterone are produced. These organs are particularly susceptible to $\mathrm{Cd}$ cytotoxicity due to their high metabolic activities and high energy demands. In this review, epidemiological and experimental studies examining $\mathrm{Cd}$ toxicities in gonads are highlighted together with studies using zinc ( $\mathrm{Zn}$ ), selenium (Se), and natural substances to reduce the effects of $\mathrm{Cd}$ on follicular genesis and spermatogenesis. Higher blood concentrations of $\mathrm{Cd}\left([\mathrm{Cd}]_{\mathrm{b}}\right)$ were associated with longer time-to-pregnancy in a prospective cohort study. Cd excretion rate $\left(\mathrm{E}_{\mathrm{Cd}}\right)$ as low as $0.8 \mu \mathrm{g} / \mathrm{g}$ creatinine was associated with reduced spermatozoa vitality, while $\mathrm{Zn}$ and Se may protect against spermatozoa quality decline accompanying $\mathrm{Cd}$ exposure. $\mathrm{E}_{\mathrm{Cd}}>0.68 \mu \mathrm{g} / \mathrm{g}$ creatinine were associated with an increased risk of premature ovarian failure by 2.5 -fold, while $[\mathrm{Cd}]_{\mathrm{b}} \geq 0.34 \mu \mathrm{g} / \mathrm{L}$ were associated with a 2.5 -fold increase in the risk of infertility in women. Of concern, urinary excretion of $\mathrm{Cd}$ at 0.68 and $0.8 \mu \mathrm{g} / \mathrm{g}$ creatinine found to be associated with fecundity are respectively $13 \%$ and $15 \%$ of the conventional threshold limit for Cd-induced kidney tubular effects of $5.24 \mu \mathrm{g} / \mathrm{g}$ creatinine. These findings suggest that toxicity of $\mathrm{Cd}$ in primary reproductive organs occurs at relatively low body burden, thereby arguing for minimization of exposure and environmental pollution by $\mathrm{Cd}$ and its transfer to the food web.
\end{abstract}

Keywords: cadmium; ovary; testis; oxidative stress; fecundity; toxicity mitigation

\section{Introduction}

Cadmium (Cd), a heavy metal in the IIB group of the periodic table, was first discovered as an impurity in zinc carbonate [1-3]. It is a rare element that occurs in the Earth's crust and the sea at $0.15 \mathrm{mg} / \mathrm{kg}$ and $1.1 \times 10^{-4} \mathrm{mg} / \mathrm{L}$, respectively [1-3]. In an elemental form $\mathrm{Cd}$ is unstable, and it forms a compound with sulfide as $\mathrm{Cd}$ sulfide (CdS), present in greenockite together with sphalerite, the zinc $(\mathrm{Zn})$ ore which contains $\mathrm{Zn}$ sulfide $(\mathrm{ZnS})$ [1-3]. Because greenockite and sphalerite are inseparable, $\mathrm{Cd}$ becomes a byproduct of mining, smelting, and refining zinc ore [1-3]. Cd has been used in many industrial processes, including as a plastic stabilizer, in the production of batteries, solar cells, pigments, alloys, plating, and coating [2,3]. The industrial application of $\mathrm{Cd}$ has resulted in the mobilization of $\mathrm{Cd}$ from geological sources to biologically accessible conditions, as does the use of phosphate fertilizers by the agricultural sector [4-6]. 
Like other metals, $\mathrm{Cd}$ is not biodegradable, and it can persist indefinitely in the environment which eases its food-chain transfer [1-3]. Because $\mathrm{Cd}$ is present in virtually all foodstuffs, diet is a major exposure source in the general non-smoking adult population worldwide [5,7-9]. Volcanic emissions, fossil fuel and biomass combustion, and cigarette smoke are additional environmental Cd sources [10-14]. The tobacco plant is a hyperaccumulator of $\mathrm{Cd}$, and it is consistently reported that blood Cd levels $\left([\mathrm{Cd}]_{\mathrm{b}}\right)$ in cigarette smokers were two- to six-fold higher than non-smokers of similar age and gender [7]. $\mathrm{Cd}$ in cigarette smoke exists as oxide form (CdO), and a volatile metallic form with high transmission rates [14]. Thus, $\mathrm{Cd}$ can enter the body from the gut and lungs, and then accumulates in human tissues to induce toxicity in the tissues/organs it deposits $[5,7,8,15]$.

The aim of this review is to provide an update of knowledge arising from recent epidemiological and experimental studies concerning ovarian and testicular toxicities of $\mathrm{Cd}$. It emphasizes on how those studies attempted to demonstrate the utility of plant substances (phytochemicals), $\mathrm{Zn}$ and selenium (Se) to offset the toxic effects of Cd in ovaries and testes, where female gametes (oocytes) and male gametes (spermatozoa) are produced together with estrogen and testosterone. Gametogenesis (oogenesis, folliculogenesis and spermatogenesis) is known to be highly susceptible to persistent toxic chemicals, such as $\mathrm{Cd}$, lead $(\mathrm{Pb})$ and mercury $(\mathrm{Hg})[16,17]$. Chelating agents are prescribed as a conventional method for treatment of $\mathrm{Pb}$ intoxication, but many side effects are reported [18], while therapeutically effective chelation therapies for $\mathrm{Cd}$ are lacking. Several candidates for mitigation of the ovarian and testicular $\mathrm{Cd}$ toxicities have been suggested, including various forms of nanoparticles (carbon nanomaterials, magnetic nanoparticles, nano-imprinted polymers, nano-based metal-organic frameworks, silica nanoparticles), probiotics, antioxidant vitamins $\mathrm{C}$ and $\mathrm{E}$, folate, and amino acids [19-21].

\section{Environmental Cadmium Exposure and Human Reproduction}

\subsection{Dietary Intake Levels of Cadmium}

The total diet study, known also as the "market basket survey", is a food safety monitoring program that has been used to estimate intake levels of various contaminants and identify their sources in the human diet. It provides a basis to define a maximum level (ML) or a maximally permissible concentration (MPC) of a given contaminant in a specific food group. Table 1 provides MPC for $\mathrm{Cd}$ in various food items according to the European Food Safety Agency (EFSA).

Table 1. Maximum permissible concentrations for cadmium in food.

\begin{tabular}{clc}
\hline No. & \multicolumn{1}{c}{ Foodstuffs } & $\begin{array}{c}\text { MPC * } \\
\text { mg/kg Wet Weight }\end{array}$ \\
\hline 1. & Meat (excluding offal) of bovine animals, sheep, pig, and poultry. & 0.05 \\
2. & Horsemeat, excluding offal. & 0.20 \\
3. & Liver of bovine animals, sheep, pig, poultry, and horse. & 0.50 \\
4. & Kidney of bovine animals, sheep, pig, poultry, and horse. & 1.0 \\
5. & Muscle meat of fish, excluding species listed in \#6 and \#7. & 0.050 \\
& Bonito (Sarda sarda), common two-banded seabream (Diplodus \\
& $\begin{array}{l}\text { vulgaris), eel (Anguilla nguilla), grey mullet (Mugil labrosus } \\
\text { labrosus), horse mackerel or scad (Trachurus spp), louvar or luvar }\end{array}$ \\
6. & $\begin{array}{l}\text { (Luvarus imperialis), mackerel (Scomber spp), sardine (Sardina } \\
\text { pilchardus), sardinops (Sardinops spp), tuna (Thunnus spp, }\end{array}$ \\
Euthynnus spp, Katsuwonus pelamis), and wedge sole & 0.10 \\
7. (Dicologoglossa cuneata). & Muscle meat of bullet tuna (Auxis spp). \\
8. & Muscle meat of anchovy (Engraulis spp) and swordfish (Xiphias \\
gladius). & 0.20 \\
\hline
\end{tabular}


Table 1. Cont.

\begin{tabular}{|c|c|c|}
\hline No. & Foodstuffs & $\begin{array}{c}\text { MPC * } \\
\mathrm{mg} / \mathrm{kg} \text { Wet Weight }\end{array}$ \\
\hline 9. & $\begin{array}{l}\text { Crustaceans, excluding brown meat of crab and excluding head } \\
\text { and thorax meat of lobster and similar large crustaceans } \\
\text { (Nephropidae and Palinuridae). }\end{array}$ & 0.50 \\
\hline 10. & Bivalve mollusks. & 1.0 \\
\hline 11. & Cephalopods (without viscera). & 1.0 \\
\hline 12. & Cereals, excluding bran, germ, wheat, and rice. & 0.10 \\
\hline 13. & Bran, germ, wheat, and rice. & 0.20 \\
\hline 14. & Soybeans. & 0.20 \\
\hline 15. & $\begin{array}{l}\text { Vegetables and fruit, excluding leaf vegetables, fresh herbs, fungi, } \\
\text { stem vegetables, root vegetables, and potatoes. }\end{array}$ & 0.050 \\
\hline 16. & $\begin{array}{l}\text { Stem vegetables, root vegetables and potatoes, excluding celeriac. } \\
\text { For potatoes the maximum level applies to peeled potatoes. } \\
\text { Leaf vegetables, fresh herbs, celeriac, and the following fungi: }\end{array}$ & 0.10 \\
\hline 17. & $\begin{array}{l}\text { Agaricus bisporus (common mushroom), Pleurotus ostreatus (Oyster } \\
\text { mushroom), Lentinula edodes (Shiitake mushroom). }\end{array}$ & 0.20 \\
\hline 18. & Fungi, excluding those listed in \#17. & 1.0 \\
\hline 19. & Food supplements excl. food supplements listed in \#20. & 1.0 \\
\hline 20. & $\begin{array}{l}\text { Food supplements consisting exclusively or mainly of dried } \\
\text { seaweed or of products derived from seaweed. }\end{array}$ & 3.0 \\
\hline
\end{tabular}

* According to Regulation (EC) No 1881/2006 latest amended by Regulation (EC) No 629/2008 [22].

Dietary intake levels of Cd, estimated from total diet studies, vary widely among populations. The Cd intake by average consumers in the U.S. [23], Spain [24], Belgium [25], Sweden [26], France [27], Korea [28], Germany [29] and China [30] were estimated as 4.63, $7.7,9.8,10.6,11.2,12.6,14.6$ and $32.7 \mu \mathrm{g} /$ day, respectively. The median Cd intake levels for women who lived in two areas of Japan affected by $\mathrm{Cd}$ pollution were estimated as 47.8 and $55.7 \mu \mathrm{g} /$ day [31]. The most significant dietary sources of $\mathrm{Cd}$ include foods that are frequently consumed in large quantities, such as rice, potatoes, wheat, leafy salad vegetables, and other cereal crops.

\subsection{Effects of Cadmium on Human Reproduction}

Although Cd was detectable in human ovaries [32], testes, epididymis, prostate glands, and seminal vesicles [33,34], limited population-based investigations have been undertaken to link $\mathrm{Cd}$ accumulations in these tissues to fecundity. In a recent population-based cohort study, higher blood concentrations of $\mathrm{Cd}\left([\mathrm{Cd}]_{b}\right)$ were associated with longer time-topregnancy (TTP), defined as the number of menstrual cycles or months of unprotected intercourse required to achieve pregnancy [34]. This prospective cohort study included 501 couples in Michigan and Texas who discontinued contraception to become pregnant. Among women, $11 \%$ smoked cigarettes while $15 \%$ and $14 \%$ of men smoked cigarettes and cigars, respectively. Compared with those who never smoked, $[\mathrm{Cd}]_{\mathrm{b}}$ levels were higher in smokers than those consumed smokeless tobacco products and never smoked. Adjusting for $[\mathrm{Cd}]_{\mathrm{b}}$ attenuated the association between cigarette smoking and TTP, particularly among women. This finding suggested that $\mathrm{Cd}$ may partially contribute to longer TTP in men and women who smoked [35]. Findings of other epidemiological studies showing the impacts of $\mathrm{Cd}$ exposure on human reproduction are highlighted in Sections 2.4 and 2.5.

\subsection{Cadmium Exposure Estimates}

$\mathrm{Cd}$ is a cumulative toxicant because no mechanisms have been evolved to eliminate it from the body. Owing to its miniscule elimination rate, the body burden of $\mathrm{Cd}$ is essentially determined by the absorption rate $[5,8]$. Numerous studies have shown that the intestinal absorption of $\mathrm{Cd}$ is mediated by transporters and receptors that the body uses to acquire iron $(\mathrm{Fe})$, calcium $(\mathrm{Ca}), \mathrm{Zn}$, and manganese $(\mathrm{Mn})$, all of which are influenced by age, physiological requirement, nutritional status, and dietary factors [5,8]. In theory, the 
absorption rate of $\mathrm{Cd}$ will rise when the body is in short supply of the elements that share absorption and transport mechanisms with $\mathrm{Cd}(\mathrm{Fe}, \mathrm{Ca}, \mathrm{Zn}, \mathrm{Mn})$. It will also rise in subjects whose diets are deficient in these elements.

Urinary concentration of $\mathrm{Cd}\left([\mathrm{Cd}]_{\mathrm{u}}\right)$ and excretion rate of $\mathrm{Cd}\left(\mathrm{E}_{\mathrm{Cd}}\right)$ can be used as a measure of kidney burden, and an indicator of a cumulative lifetime exposure. These two parameters correlate closely with $\mathrm{Cd}$ contents of kidneys, and other determinants of kidney $\mathrm{Cd}$ accumulation rate, such as age, gender, smoking, and body status of Fe, $\mathrm{Ca}, \mathrm{Zn}$ and Mn, described above $[5,8]$. [Cd $]_{\mathrm{u}}$ and $\mathrm{E}_{\mathrm{Cd}}$ have been measured in a bio-monitoring program such as the U.S. National Health and Nutrition Examination Survey (NHANES), becoming a rich data source for investigating potential adverse health effects of environmental exposures that can be generalized to the U.S. population. The geometric mean, the 50th, 75th, 90th, and 95th percentile values for $\mathrm{E}_{\mathrm{Cd}}$ in the representative U.S. general population are 0.210, $0.208,0.412,0.678,0.949 \mu \mathrm{g} / \mathrm{g}$ creatinine, respectively [36].

At any given time, blood concentration of $\mathrm{Cd}\left([\mathrm{Cd}]_{\mathrm{b}}\right)$ reflects recent exposures and the contribution from tissues and organs, especially the liver and lungs. The geometric mean, the 50 th, 75 th, 90th, and 95th percentile values for $[\mathrm{Cd}]_{b}$ in the representative U.S. general population are $0.304,0.300,0.500,1.10,1.60 \mu \mathrm{g} / \mathrm{L}$, respectively [35]. Most Cd in whole blood is contained within the cytosol of red blood cells. The $\mathrm{Cd}$ that remains in the blood plasma (serum) is bound to the amino acid histidine and proteins, such as metallothionine (MT), pre-albumin, albumin, $\alpha_{2}$-macroglobulin, and immunoglobulins G and A [37-39]. It is conceivable that a plasma/serum concentration of $\mathrm{Cd}\left([\mathrm{Cd}]_{\mathrm{S}}\right)$ is more predictive of its toxicity than those in erythrocytes because it is readily exchangeable. Presently, $[\mathrm{Cd}]_{\mathrm{S}}$ is rarely used. Nonetheless, the utility of $[\mathrm{Cd}]_{\mathrm{s}}$ has been increasingly demonstrated in recent studies, including those examining effects of $\mathrm{Cd}$ exposure on semen quality (Section 2.5). Further, $[\mathrm{Cd}]_{\mathrm{s}} \geq 0.73 \mu \mathrm{g} / \mathrm{L}$ were associated with a 2.5 -fold increase in the risk of obstructive lung disease among participants in NHANES 2007-2010 [40], while [Cd] in the highest quartile were associated with a 2.8-fold increase in the risk of wheeze and asthma in NHANES 2007-2012 participants, aged 20-79 years [41]. In a Japanese-population-based study $\left(n=1144\right.$, aged $>19$ years, the median $[\mathrm{Cd}]_{\mathrm{S}}$ of $\left.0.06 \mu \mathrm{g} / \mathrm{L}\right),[\mathrm{Cd}]_{\mathrm{s}}$ in the highest quintile was associated with a 1.7-fold increase in risk of hypertension, compared with $[\mathrm{Cd}]_{\mathrm{s}}$ in the lowest quintile [42].

\subsection{Epidemiological Investigations on Effects of Cadmium on Fecundity in Women}

Table 2 summarizes data from six studies examining impacts of environmental $\mathrm{Cd}$ exposure on fecundity in women in the U.S. [43-46], China [47] and Korea [48].

Table 2. Epidemiological evidence for the effects of cadmium on fecundity in women.

\begin{tabular}{|c|c|c|}
\hline Effects Observed & Study Design/Populations & Risk Estimates \\
\hline Infertility [43]. & $\begin{array}{l}\text { NHANES 2013-2016 } \\
\text { participants, aged } 20-39 \text { years. } \\
\text { Data from } 42 \text { pregnant and } 82 \\
\text { infertile women were } \\
\text { analyzed. GM for }[\mathrm{Cd}]_{\mathrm{b}} \text { was } \\
0.26 \mu \mathrm{g} / \mathrm{L} \text {. }\end{array}$ & $\begin{array}{l}\text { OR for infertility increased by } 1.84 \text {-fold } \\
\text { per a } 2 \text {-fold increment of }[\mathrm{Cd}]_{\mathrm{b}} \text {. OR for } \\
\text { infertility increased by } 1.15-\text { and } 2.47 \text {-fold, } \\
\text { comparing }[\mathrm{Cd}]_{\mathrm{b}} 0.20-0.33 \mu \mathrm{g} / \mathrm{L} \text {, } \\
0.34-5.14 \mu \mathrm{g} / \mathrm{L} \text { with }[\mathrm{Cd}]_{\mathrm{b}} \\
0.07-0.19 \mu \mathrm{g} / \mathrm{L} \text {. }\end{array}$ \\
\hline Endometriosis [44]. & $\begin{array}{l}\text { NHANES } 1999-2002 \\
\text { participants }(n=1425) \text { aged } \\
20-49 \text { years. GM for }[\mathrm{Cd}]_{\mathrm{b}} \text { in } \\
\text { women with endometriosis } \\
\text { was } 0.53 \mu \mathrm{g} / \mathrm{L}, 20.8 \% \text { higher } \\
\text { than those without } \\
\text { endometriosis. }\end{array}$ & $\begin{array}{l}\text { OR for endometriosis increased by } \\
3.39 \text {-fold, comparing }[\mathrm{Cd}]_{\mathrm{b}} \geq 0.5 \mu \mathrm{g} / \mathrm{L} \text { ) } \\
\text { with }[\mathrm{Cd}]_{\mathrm{b}}<0.3 \mu \mathrm{g} / \mathrm{L} \text { after adjusting for } \\
\text { age, race/ethnicity, smoking status, use } \\
\text { of birth control pills, and exposure to } \\
\text { lead and mercury. }\end{array}$ \\
\hline
\end{tabular}


Table 2. Cont.

\begin{tabular}{|c|c|c|}
\hline Effects Observed & Study Design/Populations & Risk Estimates \\
\hline $\begin{array}{l}\text { Polycystic ovary } \\
\text { syndrome } \\
\text { (PCOS) [45]. }\end{array}$ & $\begin{array}{l}\text { A prospective cohort study of } \\
251 \text { healthy women, aged } \\
18-44 \text { years (New York, NY, } \\
\text { U.S.). Median }[\mathrm{Cd}]_{\mathrm{b}} \text { was } \\
0.30 \mu \mathrm{g} / \mathrm{L} .\end{array}$ & $\begin{array}{l}\text { The probability of having PCOS was } \\
\text { increased by } 18 \% \text { per } 0.1 \mu \mathrm{g} / \mathrm{L} \text { increment } \\
\text { of }[\mathrm{Cd}]_{\mathrm{b}} \text {, together with } 2.2 \%, 2.9 \% \text { and } \\
7.7 \% \text { increments of serum concentrations } \\
\text { of testosterone, sex hormone-binding } \\
\text { globulin and AMH, respectively. PCOS } \\
\text { was based on serum AMH and } \\
\text { testosterone levels. }\end{array}$ \\
\hline $\begin{array}{l}\text { Low ovarian } \\
\text { reserve [46]. }\end{array}$ & $\begin{array}{l}\text { NHANES } 1988-1994 \\
\text { participants }(n=1681) \text { aged } \\
35-49 \text { years. Additional data } \\
\text { from } 65 \text { postmenopausal } \\
\text { women were analyzed. }\end{array}$ & $\begin{array}{l}\text { RR for low ovarian reserve was increased } \\
\text { by } 1.4-, 1.6-\text { and } 1.8 \text {-fold, comparing } \\
{[\mathrm{Cd}]_{\mathrm{u}} 0.16-0.38,0.39-0.77 \text { and }>} \\
0.77 \mu \mathrm{g} / \mathrm{L} \text { with }[\mathrm{Cd}]_{\mathrm{u}}<0.16 \mu \mathrm{g} / \mathrm{L} \text {, } \\
\text { respectively. Low ovarian reserve was } \\
\text { defined as }[\mathrm{FSH}]_{\mathrm{s}} \geq 10 \mathrm{IU} / \mathrm{L} \text {. }\end{array}$ \\
\hline $\begin{array}{l}\text { Ovarian } \\
\text { insufficiency [47]. }\end{array}$ & $\begin{array}{l}\text { Chinese women in Zhejiang } \\
\text { Province, } 169 \text { cases, } 209 \\
\text { controls, aged } 35-45 \text { years. } \\
\text { Median for } E_{\text {Cd }} \text { in cases was } \\
0.58 \mu \mathrm{g} / \mathrm{g} \text { creatinine, } 25.6 \% \\
\text { higher than controls. }\end{array}$ & $\begin{array}{l}\text { OR for ovarian insufficiency was } \\
\text { increased by } 2.5 \text {-fold, comparing } \mathrm{E}_{\mathrm{Cd}}> \\
0.68 \mu \mathrm{g} / \mathrm{g} \text { creatinine with } \mathrm{E}_{\mathrm{Cd}}< \\
0.37 \mu \mathrm{g} / \mathrm{g} \text { creatinine. } \mathrm{E}_{\mathrm{Cd}} \text { positively } \\
\text { associated with }[\mathrm{FSH}]_{\mathrm{s}} \text { and }[\mathrm{LH}]_{\mathrm{s}} \text {, while } \\
\text { showing inverse associations with } \\
\left.[\mathrm{AMH}]_{\mathrm{s}} \text { and [estradiol }\right]_{\mathrm{s}} \text {. } \\
\text { Ovarian insufficiency was defined as } \\
{[\mathrm{FSH}]_{\mathrm{s}} \geq 25 \mathrm{IU} / \mathrm{L} \text {. }}\end{array}$ \\
\hline $\begin{array}{l}\text { Ovarian } \\
\text { failure [48]. }\end{array}$ & $\begin{array}{l}\text { Korean women in Soul } \\
(n=283) \text {, aged } 30-45 \text { years. } \\
\text { GM for }[\mathrm{Cd}]_{\mathrm{b}} \text { was } 0.97 \mu \mathrm{g} / \mathrm{L} \text {. }\end{array}$ & $\begin{array}{l}\text { Ovarian reserve inversely associated with } \\
\left.[\mathrm{Cd}]_{\mathrm{b}} \text { (adjusted } \beta=-0.34, p=0.02\right) \text {. An } \\
\text { inverse association of ovarian reserve and } \\
{[\mathrm{Cd}]_{\mathrm{b}} \text { was particularly strong in } 30-35 \text {-yr }} \\
\text { age group (adjusted } \beta=-0.43(p=0.01 \text { ). } \\
\text { Ovarian reserve was based }[\mathrm{AMH}]_{\mathrm{s}} \text {. }\end{array}$ \\
\hline
\end{tabular}

NHANES, National Health and Nutrition Examination Survey; $n$, sample size; GM, geometric mean; $[\mathrm{x}]_{\mathrm{u}}$, urinary concentration of $x ; E_{x}$, excretion rate of $x ;[x]_{b}$, blood concentration of $x ;[x]_{s}$, serum concentration of $x ; O R$, odds ratio; RR, risk ratio; $\mathrm{FSH}$, follicle-stimulating hormone; $\mathrm{LH}$, luteinizing hormone; $\mathrm{AMH}$, anti-Mullerian hormone; PCOS, polycystic ovary syndrome.

An increment of $[\mathrm{Cd}]_{b}$ by two-fold was associated with 1.84 -fold increase in risk of infertility in a study of women, aged 20-39 years, who participated in NHANES 20132016 [43]. The risk of infertility rose by 1.15 - and 2.47 -fold, comparing $[\mathrm{Cd}]_{\mathrm{b}}$ of $0.20-0.33$, and $0.34-5.14 \mu \mathrm{g} / \mathrm{L}$ with $[\mathrm{Cd}]_{\mathrm{b}} \leq 0.19 \mu \mathrm{g} / \mathrm{L}$.

An association of $\mathrm{Cd}$ exposure with an increased risk of endometriosis was evident from a study of women, aged 20-49 years, enrolled in NHANES 1999-2002 [44]. Comparing $[\mathrm{Cd}]_{\mathrm{b}} \geq 0.5$ versus $<0.3 \mu \mathrm{g} / \mathrm{L}$, OR for endometriosis was increased by 3.39-fold after adjustment for age, lead, mercury, race/ethnicity, smoking and use of birth control pills. An association of $\mathrm{Cd}$ exposure with an increased risk of polycystic ovary syndrome (PCOS) phenotype was seen in a prospective cohort study of healthy premenopausal women, aged 18-44 years [45]. Per $0.1 \mu \mathrm{g} / \mathrm{L}$ increment of $[\mathrm{Cd}]_{b}$, the probability of a mild polycystic ovary syndrome phenotype was $18 \%$ higher, serum testosterone, sex hormone-binding globulin, and AMH were $2.2 \%, 2.9 \%$, and $7.7 \%$ higher. Based on these data, $\mathrm{Cd}$ may act as an endocrine disruptor affecting the hypothalamic-pituitary-gonadal axis [45].

In a study of women, aged 35-49 years, who participated in NHANES 1988-1994, a dose-response relationship was seen between $[\mathrm{Cd}]_{\mathrm{u}}$ and ovarian reserve decline, defined by serum concentration of follicle-stimulating hormone $\left([\mathrm{FSH}]_{\mathrm{s}}\right) \geq 10 \mathrm{IU} / \mathrm{L}$ [46]. The risk of ovarian reserve depletion was increased by 1.4-, 1.6- and 1.8-fold, comparing [Cd $]_{\mathrm{u}}$ of $0.16-0.38,0.39-0.77$ and $>0.77 \mu \mathrm{g} / \mathrm{L}$ with $[\mathrm{Cd}]_{\mathrm{u}}<0.16 \mu \mathrm{g} / \mathrm{L}$, respectively. An effect of $\mathrm{Cd}$ exposure and ovarian reserve has also been observed in Chinese and Korean studies [47,48]. In a Chinese study, OR for ovarian insufficiency was increased by 2.5 -fold, comparing 
$\mathrm{E}_{\mathrm{Cd}}>0.68 \mu \mathrm{g} / \mathrm{g}$ creatinine with $\mathrm{E}_{\mathrm{Cd}}<0.37 \mu \mathrm{g} / \mathrm{g}$ creatinine [47]. Median $\mathrm{E}_{\mathrm{Cd}}$ in cases of $0.58 \mu \mathrm{g} / \mathrm{g}$ creatinine was $25.6 \%$ higher than controls, and $\mathrm{E}_{\mathrm{Cd}}$ showed positive associations with serum concentrations of FSH and luteinizing hormone (LH) while showing inverse associations with serum concentrations of $\mathrm{AMH}$ and estradiol. An inverse association of $[\mathrm{Cd}]_{\mathrm{b}}$ and serum concentration of $\mathrm{AMH}$ was seen in a study of Korean women, aged $30-45$ years. A particularly strong inverse association of $[\mathrm{AMH}]_{\mathrm{s}}$ with $[\mathrm{Cd}]_{\mathrm{b}}$ was in women aged 30-35 years (adjusted $\beta=-0.43, p=0.01$ ) [48].

Of the six studies in women, five were reviewed using population-based design [43-46,48], and one center-based, case-control design study [47] was used. Accordingly, all participants were assumed to be environmentally exposed to $\mathrm{Cd}$, and the diet was the most likely environmental $\mathrm{Cd}$ source. Regardless of the study designs, the environmental exposure to $\mathrm{Cd}$ reflected by $[\mathrm{Cd}]_{\mathrm{b}},[\mathrm{Cd}]_{\mathrm{u}}$ and $\mathrm{E}_{\mathrm{Cd}}$ reported for study women were comparable. They could be considered to be low to moderate. The body burden of $\mathrm{Cd}$ as $[\mathrm{Cd}]_{\mathrm{u}}$ in Chinese women (GM for [Cd $]_{u}$ of $0.42 \mu \mathrm{g} / \mathrm{L}$ in POI cases and $0.28 \mu \mathrm{g} / \mathrm{L}$ in controls) were comparable to the GM for $[\mathrm{Cd}]_{\mathrm{u}}$ of $0.30 \mu \mathrm{g} / \mathrm{L}$ recorded in the U.S. women study $[47,48]$. The average $[\mathrm{Cd}]_{b}$ level in Korean women was three times higher than the average in U.S. women of the same age $\left([\mathrm{Cd}]_{\mathrm{b}} 0.97\right.$ vs. $\left.0.30 \mu \mathrm{g} / \mathrm{L}\right)[45,48]$.

\subsection{Epidemiological Investigations on Effects of Cadmium on Fecundity in Men}

Evidence for adverse effects of environmental exposure to $\mathrm{Cd}$ on male fecundity comes from studies in which semen (sperm) quality parameters were examined using the criteria prescribed by the World Health Organization [49]. The four main spermatozoa quality parameters were spermatozoa concentration, viability, morphology, and motility [49,50]. These parameters then were tested for their associations with $\mathrm{Cd}$ exposure levels, reflected by the levels of $\mathrm{Cd}$ in samples of urine, whole blood, blood plasma/serum and seminal plasma. Table 3 summarizes data from six research studies undertaken in Taiwan [51], Italy [52], China [53], Nigeria [54], Spain [55] and India [56].

Table 3. Epidemiological evidence for the effects of cadmium on semen quality.

\begin{tabular}{|c|c|c|}
\hline Effects Observed & Study Design/Populations & Risk Estimates \\
\hline $\begin{array}{l}\text { Spermatozoa } \\
\text { vitality } \\
\text { [51]. }\end{array}$ & $\begin{array}{l}\text { Taiwan, } n=196, \text { mean age } 38, \\
62(32 \%) \text { had normal semen } \\
\text { quality. Mean for }[\mathrm{Cd}]_{\mathrm{u}} \text { was } \\
0.7 \mu \mathrm{g} / \mathrm{L} \text { and mean for } \mathrm{E}_{\mathrm{Cd}} \\
\text { was } 0.5 \mu \mathrm{g} / \mathrm{g} \text { creatinine. }\end{array}$ & $\begin{array}{l}\mathrm{E}_{\mathrm{Cd}} \geq 0.8 \mu \mathrm{g} / \mathrm{g} \text { creatinine were } \\
\text { associated in an increased risk of } \\
\text { spermatozoa viability decline. } \\
\text { Percentages of sperm viability correlated } \\
\text { inversely with }[\mathrm{Cd}]_{\mathrm{u}}(r=-0.216) \text { and } \\
\mathrm{E}_{\mathrm{Cd}}(r=-0.301) .\end{array}$ \\
\hline $\begin{array}{l}\text { Spermatozoa } \\
\text { counts, } \\
\text { spermatozoa } \\
\text { motility/Se as a } \\
\text { protective factor } \\
\text { [52]. }\end{array}$ & $\begin{array}{l}\text { Italy, } n=179 \text {, aged } 18-46 \\
\text { years, } 131(73.2 \%) \text { had two or } \\
\text { more at abnormal sperm } \\
\text { quality parameters. Seminal } \\
\text { plasma Cd was more } \\
\text { predictive of semen quality } \\
\text { than blood Cd. }\end{array}$ & $\begin{array}{l}\text { In men with abnormal semen quality, the } \\
\text { median level for seminal plasma Cd was } \\
2.2 \text {-fold higher }(0.93 \mathrm{vs} .0 .43 \mu \mathrm{g} / \mathrm{L}) \text {, while } \\
\text { the median level for Se was } 10.6 \text {-fold } \\
\text { lower }(1.17 \mathrm{vs} .12 .36 \mu \mathrm{g} / \mathrm{L}) \text {, compared } \\
\text { to controls. } \\
\text { Sperm concentration, total sperm count } \\
\text { and progressive motility were increased } \\
\text { with increment of seminal plasma } \\
\text { Se levels. }\end{array}$ \\
\hline
\end{tabular}


Table 3. Cont.

\begin{tabular}{|c|c|c|}
\hline Effects Observed & Study Design/Populations & Risk Estimates \\
\hline $\begin{array}{l}\text { Spermatozoa } \\
\text { motility, } \\
\text { Zn as a protective } \\
\text { factor [53]. }\end{array}$ & $\begin{array}{l}\text { China (Wuhan), } n=746 \text {, aged, } \\
18-55 \text { years, } \\
482(65 \%) \text { had normal } \\
\text { spermatozoa quality, 238, 200, } \\
66 \text {, and } 56 \text { men were those } \\
\text { with low total motility, low } \\
\text { spermatozoa progressive } \\
\text { motility, low concentration, } \\
\text { and low total spermatozoa } \\
\text { counts, respectively. }\end{array}$ & $\begin{array}{l}\text { Seminal plasma Cd levels inversely } \\
\text { associated with progressive sperm } \\
\text { motility and total motility. } \\
\text { Seminal plasma Zn levels positively } \\
\text { associated with sperm concentrations. } \\
\text { Compared with seminal plasma Zn } \\
\text { quartile } 1 \text {, sperm concentrations rose by } \\
13 \%, 23 \% \text {, and } 25 \% \text { in seminal plasma Zn } \\
\text { quartiles 2, } 3 \text { and } 4 \text {, respectively. }\end{array}$ \\
\hline $\begin{array}{l}\text { Spermatozoa } \\
\text { concentration [54]. }\end{array}$ & $\begin{array}{l}\text { Nigeria, } n=130 \text {, aged } 20-60 \\
\text { years, } \\
30,20 \text { and } 50 \text { were } \\
\text { azoospermic, oligozoospermic } \\
\text { and normozoospermic. }\end{array}$ & $\begin{array}{l}\text { Serum Cd concentrations inversely } \\
\text { correlated with sperm concentrations. } \\
\text { The means for serum Cd levels in } \\
\text { azoospermic and oligospermic were } 0.305 \\
\text { and } 0.287 \mu \mathrm{g} / \mathrm{L} \text {, respectively. These } \\
\text { means for serum Cd levels were higher } \\
\text { than normospermic group }(0.219 \mu \mathrm{g} / \mathrm{L}) \text {. }\end{array}$ \\
\hline $\begin{array}{l}\text { Sperm } \\
\text { motility [55]. }\end{array}$ & $\begin{array}{l}\text { Spain, } n=61 \text {, age } 33.5 \pm 3.8 \\
\text { years, } \\
30 \text { infertile cases and } \\
31 \text { controls, } \\
\text { The respective GM values for } \\
{[\mathrm{Cd}]_{\mathrm{b}} \text {, serum Cd and seminal }} \\
\text { plasma Cd were } 1.0,0.8, \\
0.8 \mu \mathrm{g} / \mathrm{L} \text {. }\end{array}$ & $\begin{array}{l}\text { Seminal plasma Cd levels positively } \\
\text { associated with percentages of immotile } \\
\text { sperm after adjustment for age, BMI, and } \\
\text { smoking ( } \beta=4.9 ; 95 \% \mathrm{CI}, 0.84,9.1 \text { ). } \\
\text { An increment of seminal plasma Cd from } \\
0.7 \text { to } 1.0 \mu \mathrm{g} / \mathrm{L} \text { was associated with a rise } \\
\text { of immotile sperms by } 24.3 \% \text {. }\end{array}$ \\
\hline $\begin{array}{l}\text { Sperm motility and } \\
\text { concentration [56]. }\end{array}$ & $\begin{array}{l}\text { India (New Delhi), } n=119, \\
\text { aged } 20-43 \text { years, } \\
73 \text { infertile cases and } \\
46 \text { controls. }\end{array}$ & $\begin{array}{l}\text { Seminal plasma Cd levels inversely } \\
\text { correlated with sperm concentrations } \\
(r=-0.33) \text { and sperm motility }(r=-0.33) \text {. } \\
\text { The mean for seminal plasma in cases } \\
\text { was } 0.591 \mu \mathrm{g} / \mathrm{L}, 31.2 \% \text { higher than } \\
\text { controls. } \\
\text { The means for seminal plasma Cd were } \\
23.9 \% \text { and } 30.8 \% \text { higher in men with low } \\
\text { sperm concentrations and impaired } \\
\text { sperm motility, compared to controls. }\end{array}$ \\
\hline
\end{tabular}

Spermatozoa quality parameters were based on WHO criteria [36]. N, sample size; $[\mathrm{x}]_{\mathrm{u}}$, urinary concentration of $x ; E_{x}$, excretion rate of $x ;[x]_{b}$, blood concentration of $x ;[x]_{s}$, serum concentration of $x ;[x]_{s p}$, seminal plasma concentration of $\mathrm{x} ; \mathrm{OR}$, odds ratio.

A Taiwanese study included men (mean age 38 years) who underwent an annual health examination at a main municipal hospital in the southern region of Taiwan [51]. Among 186 men recruited to the study, half (50\%) were smokers and 62 (33\%) had normal semen quality parameters (spermatozoa concentration, motility, viability, and morphology) by WHO criteria. Cd was detected in $>98.5 \%$ urine samples from study subjects with mean (SD) values for $[\mathrm{Cd}]_{\mathrm{u}}$ and $\mathrm{E}_{\mathrm{Cd}}$ of $0.7(0.6) \mu \mathrm{g} / \mathrm{L}$ and $0.5(0.3) \mu \mathrm{g} / \mathrm{g}$ creatinine, respectively. $[\mathrm{Cd}]_{\mathrm{u}}$ inversely correlated with sperm viability $(r=-0.216, p=0.006)$, as did $\mathrm{E}_{\mathrm{Cd}}(r=-0.301$, $p=0.001) . \mathrm{E}_{\mathrm{Cd}} \geq 0.8 \mu \mathrm{g} / \mathrm{g}$ creatinine were associated with an enhanced risk of sperm viability decline, compared with $\mathrm{E}_{\mathrm{Cd}} \leq 0.4 \mu \mathrm{g} / \mathrm{g}$ creatinine. The relationship seen between reduced sperm vitality and $\mathrm{E}_{\mathrm{Cd}}$ was confirmed by a stepwise multiple regression analysis. Thus, data from the Taiwanese study linked long term $\mathrm{Cd}$ exposure, reflected by $\mathrm{E}_{\mathrm{Cd}}$, to decreased sperm viability.

In an Italian study, subjects were drawn from one industrial area and one agricultural area of eastern Sicily (South Italy) [52]. Among 179 men, 48 (26.8\%) had normal sperm quality parameters, while $131(73.2 \%)$ showed abnormality in more than one sperm quality parameters. Although both groups had the same median for blood Cd of $0.32 \mu \mathrm{g} / \mathrm{L}$, the 
median for seminal plasma $\mathrm{Cd}$ in men with abnormal semen quality parameters was 2.16-fold higher than those with normal semen quality parameters ( $0.93 \mathrm{vs} .0 .43 \mu \mathrm{g} / \mathrm{L})$. Thus, seminal plasma $\mathrm{Cd}$ appeared to be more predictive of an abnormal semen quality than blood Cd. The median for seminal plasma Se in men with abnormal semen quality parameters was 10.6-fold lower than those with normal sperm parameters (1.17 versus $12.36 \mu \mathrm{g} / \mathrm{L})$. The median for sperm Se content in men with abnormal sperm parameters was $13.5 \%$ lower, compared to the control (0.193 versus $0.219 \mu \mathrm{g} / \mathrm{g}$ ). A median for seminal plasma Cd levels in men with total sperm counts below WHO reference value was 2.17fold higher than those with normal total sperm counts $(1.43$ versus $0.66 \mu \mathrm{g} / \mathrm{L})$. Relative to median value, seminal plasma $\mathrm{Cd}$ levels at 75th percentile or higher were associated respectively with risks of having abnormal total sperm counts (OR 4.48, 95\%CI 0.25-80) and abnormal sperm motility (OR 3.45, 95\% CI 0.77-16). An interaction analysis suggested that Se may have minimized a decline in semen quality associated with Cd exposure [52].

A Chinese study included 746 men, aged 18-55 years, who underwent investigation for subfertility at the Wuhan Reproductive Medicine Center [53]. Among study subjects, $482(65 \%)$ men had normal sperm quality parameters. The numbers of men showing low sperm total motility, low sperm progressive motility, low sperm concentrations, and low total sperm counts were 238, 200, 66 and 56, respectively. Inverse associations were seen between seminal plasma $\mathrm{Cd}$ levels and sperm motility (progressive and total motility). The inverse associations of seminal plasma $\mathrm{Cd}$ with progressive and total sperm motility persisted when other elements were included in a model. Likewise, a positive association of seminal plasma $\mathrm{Zn}$ with sperm concentrations was retained when other elements were included in a model. Compared with seminal plasma Zn quartile 1, sperm concentrations rose by $13 \%, 23 \%$, and $25 \%$ in the seminal plasma Zn quartiles 2, 3, and 4, respectively.

In a Nigerian case-control study of men aged 20-60 years who underwent investigations for infertility, 30, 20, and 50 were azoospermic (no spermatozoa in semen), oligozoospermic (low sperm concentrations $<20 \times 10^{6} / \mathrm{mL}$ ) and normozoospermic (sperm concentration greater than $>20 \times 10^{6} / \mathrm{mL}$ ), respectively [54]. The corresponding means for serum concentration of $\mathrm{Cd}\left([\mathrm{Cd}]_{\mathrm{s}}\right)$ in these three groups were $0.305 \pm 9.61,0.287 \pm 10.31$ and $0.219 \pm 14.43 \mu \mathrm{g} / \mathrm{L}$, respectively $(p=0.018)$. The mean for serum $\mathrm{Cd}$ in azoospermic and oligospermic groups was higher than in the normospermic group. An inverse correlation was seen between serum $\mathrm{Cd}$ concentrations and spermatozoa concentrations.

In a Spanish study [55], 30 cases and 31 normospermic controls, mean age 33.5 years, were recruited from three infertility centers using semen quality criteria prescribed by the WHO [49]. Among 61 men, 31\% were smokers and the GM values for blood Cd, serum Cd, and seminal plasma $\mathrm{Cd}$ were 1.0, 0.8, and $0.8 \mu \mathrm{g} / \mathrm{L}$, respectively. After adjustment for age, $\mathrm{BMI}$ and smoking habits, seminal plasma $\mathrm{Cd}$ was positively associated with the percentage of immotile sperms $(\beta=4.9 ; 95 \% \mathrm{CI}, 0.84,9.1)$. An increase in seminal plasma Cd from 0.7 to $1.0 \mu \mathrm{g} / \mathrm{L}$ resulted in $24.3 \%$ increment of immotile sperms [55].

In an Indian study, 73 infertile cases, 46 controls aged 20-43 years were recruited from those who attended the Andrology Laboratory of Reproductive Biology Department, All India Institute of Medical Sciences, New Delhi [56]. Among 119 men, 59 (49.6\%), and 71 (59.7\%) men had low sperm concentrations and impaired sperm motility, respectively. Seminal plasma $\mathrm{Cd}$ concentrations inversely associated with sperm concentrations $(r=-0.33)$ and sperm motility $(r=-0.33)$. The adjusted mean for seminal plasma Cd was 31.2\% higher in cases than the control $(0.591$ versus $0.403 \mu \mathrm{g} / \mathrm{L})$. The adjusted means for seminal plasma Cd were respectively $23.9 \%$ and $30.8 \%$ higher in men with low sperm concentrations and impaired sperm motility than those with normal sperm concentrations and normal sperm motility.

\section{Metal Binding Proteins in the Ovary and Testis}

Metallothioneins (MTs), a group of low molecular weight (6-7 kDa) metal binding proteins can sequester both $\mathrm{Cd}$ and zinc (Zn) [57]. By virtue of the high molar cysteine content of $33 \%$, MTs act as a scavenger of free radicals, notably hydroxyl and superoxide 
radicals, thereby protecting cells from oxidative damage [57]. Hence, it is thought that cells lacking the ability to synthesize MT are susceptible to cadmium toxicity [58]. In cadmium-treated laying hens, MT protein and MT mRNA, Cd and Zn-MT were detected in the follicle walls of the ovaries, but not in the follicle yolks [59]. In rats treated with $\mathrm{CdCl}_{2}$, vascular damage, testicular necrosis, degenerative changes in ovaries, and loss of reproductive potency were observed [60-62]. Rat and mouse testes are highly susceptible to the necrotizing and carcinogenic effects of $\mathrm{Cd}$ [61].

Unlike livers and kidneys, however, effects of $\mathrm{Cd}$ in ovaries and testes were unrelated with changes in MT protein or MT mRNA levels [60-63]. The high sensitivity to Cd toxicity in ovaries may thus be attributable to a lack of MT expression [64]. This phenomenon was seen in a study using Syrian hamsters [64]. The Syrian hamster ovaries underwent a hemorrhagic necrosis when exposed to $\mathrm{Cd}$, as did the testes. An analysis of amnio acid sequences of cytosolic ovarian protein, isolated by reverse-phase HPLC, showed that the ovarian protein contained much less cysteine than MT. Furthermore, the ovarian metal binding protein contained a significant amount of aromatic amino acids (phenylalanine) and had higher glutamate molar content than MT, but lacked leucine, and arginine. Thus, Syrian hamster ovaries contained a specific metal binding protein distinct from MT [64]. Of note, the expression of ovarian specific metal-binding protein was not induced by $\mathrm{Zn}$ treatment, although the ovaries from $\mathrm{Zn}$-treated hamsters showed resistance to necrosis, caused by $\mathrm{Cd}$. Further research is required to unravel the mechanism underlying the resistance to $\mathrm{Cd}$-induced necrosis after $\mathrm{Zn}$ treatment.

\section{The Cellular Toxic Mechanisms of Cadmium}

Owing to the multiplicity of adverse effects, the exact mechanisms underlying cellular toxicity of $\mathrm{Cd}$ remain elusive. Experimental studies attempting to elucidate how $\mathrm{Cd}$ affects cells are abundant. Consequently, several mechanisms have been postulated, such as altered gene expression, apoptosis, oxidative stress, aberrant cell signaling, and disruption of endocrine system $[65,66]$. However, it is noteworthy that $\mathrm{Cd}$ must first enter cells to cause toxicity and that members of $\mathrm{Zn}$ transporters of the $\mathrm{Zrt}$ - and Irt-related protein (ZIP) family, such as ZIP8 and ZIP14, have been shown to mediate Cd uptake by cells [67-69]. Indeed, ZIP8 has been shown to be involved in Cd-induced testicular injury [70-72].

Numerous studies have shown that $\mathrm{Cd}$ disrupted cellular redox homeostasis by promoting the generation of reactive oxygen species (ROS), i.e., superoxide ion, hydrogen peroxide and hydroxyl radicals, while suppressing cellular antioxidant systems [73-75]. Examples of antioxidant enzymes affected by $\mathrm{Cd}$ are catalase, manganese superoxide dismutase (Mn-SOD), zinc and copper superoxide dismutase (Zn/Cu-SOD or SOD1) [73]. In mitochondria, $\mathrm{Cd}$ reduced cell respiration and oxidative phosphorylation, even in low concentrations [65]. Other reported toxic effects of $\mathrm{Cd}$ are depletion of reduced glutathione (GSH), inactivation of proteins with sulfhydryl groups and dysregulation of ROS production [75].

Due to high energy demands and autophagy reliance, gonads are highly susceptible to mitochondrial toxicants such as $\mathrm{Cd}$. An effect of $\mathrm{Cd}$ on mitochondrial membrane potential, leading less ATP synthesis and enhanced ROS formation was evident from a study using the human granulosa-like tumor (KGN) cells [76], known to express FSH receptor and retain progesterone synthesis similar to those of normal human ovarian granulosa cells [77]. Likewise, a study using the rat Leydig tumor cell line, R2C, has linked effects of Cd on mitochondrial membrane potential and cAMP production to a reduction in progesterone secretion [78]. A follow-up study has identified the suppression of mitochondrial expression of dihydrolipoamide dehydrogenase (LDH) enzyme by $\mathrm{Cd}$ to underlie a fall of progesterone synthesis in R2C cells [79]. Knockdown of the mitochondrial LDH gene expression reduced progesterone synthesis by $40 \%$ as did Cd treatment [79].

In rats, a single i.p. $\mathrm{Cd}$ at 0.5 or $1.0 \mathrm{mg} / \mathrm{kg}$ was sufficient to adversely affect the differentiation of Leydig cells, leading to an irreversible loss of their regenerative capacity, and a fall of serum testosterone and LH 41,55, and 76 days after Cd treatment [80]. A 
marked fall in serum testosterone was observed in another study using C57BL/6J mice treated with i.p. Cd at $1.0 \mathrm{mg}$ per $\mathrm{kg}$ of body weight for 1 week [81]. The decrease in serum testosterone was attributed to an elevation of heme oxygenase- 1 expression induced by $\mathrm{Cd}$, causing a release of iron from heme moiety, lipid peroxidation and death of Leydig cells [81]. Cd-induced germ cell death has been observed and attributed to autophagy in Sertoli cells in rats given a single i.p. $\mathrm{Cd}$ at $2 \mathrm{mg} / \mathrm{kg}$ which produced serum $\mathrm{Cd}$ concentrations of 4-10 $\mu \mathrm{g} / \mathrm{L}$, and testicular Cd contents of $0.2-0.3 \mu \mathrm{g} / \mathrm{g}$ wet weight [82].

\section{Experimental Trials to Mitigate Ovarian Toxicity}

Table 4 summarizes studies in which various natural substances, chemicals and a nutritionally essential metal $\mathrm{Zn}$ were tested for their propensities to reduce toxic effects of $\mathrm{Cd}$ accumulation in ovaries.

Table 4. Experimental ameliorating ovarian cadmium toxicities.

\begin{tabular}{|c|c|c|c|c|}
\hline $\begin{array}{c}\text { Cadmium } \\
\text { Dose/Form/Species }\end{array}$ & Toxic Signs & Substance & Beneficial Effects & References \\
\hline $\begin{array}{c}50 \mathrm{mg} / \mathrm{L} \text { as } \mathrm{CdCl}_{2} \\
\text { p.o. } \\
\text { Wistar rats }\end{array}$ & $\begin{array}{l}\text { Extended estrous cycle; } \\
\text { decreased number of } \\
\text { primary and antral follicles; } \\
\text { larger number of atretic } \\
\text { follicles. }\end{array}$ & Melatonin & $\begin{array}{l}\text { Improved estrous cycle } \\
\text { duration; improvement in } \\
\text { count of primary, secondary, } \\
\text { antral and atretic follicles. }\end{array}$ & $\begin{array}{c}\text { Kechiche et al., } \\
2020 \text { [83] }\end{array}$ \\
\hline $\begin{array}{c}100 \mathrm{mg} / \mathrm{kg} \text { b.w. } \mathrm{CdCl}_{2} \\
\text { p.o. } \\
\text { Wistar rats }\end{array}$ & $\begin{array}{l}\text { Alteration of the } \\
\text { cytoarchitecture of the } \\
\text { ovaries. }\end{array}$ & Hibiscus sabdariffa & $\begin{array}{l}\text { Restoration of } \\
\text { cytoarchitecture; follicle } \\
\text { proliferation. }\end{array}$ & $\begin{array}{c}\text { Oyewopo et al., } \\
2020 \text { [84] }\end{array}$ \\
\hline $\begin{array}{c}2 \mathrm{mg} / \mathrm{kg} \mathrm{CdCl} 2 \\
\text { p.o. } \\
\text { Wistar rats }\end{array}$ & $\begin{array}{c}\text { Severe tissue } \\
\text { necrosis; follicular cell } \\
\text { degeneration, atresia, and } \\
\text { no formation of new } \\
\text { follicles. }\end{array}$ & Xylopia aethiopica & $\begin{array}{l}\text { Significant improvement of } \\
\text { the ovarian histological } \\
\text { structure and increment of } \\
\text { follicle numbers. }\end{array}$ & $\begin{array}{c}\text { Godam et al., } \\
2020 \text { [85] }\end{array}$ \\
\hline $\begin{array}{c}5 \mathrm{mg} / \mathrm{kg} \text { b.w. } \mathrm{CdCl}_{2} \\
\text { p.o. } \\
\text { Sprague Dawley rats }\end{array}$ & $\begin{array}{l}\text { Increased number of antral } \\
\text { and atretic follicles; } \\
\text { morphological } \\
\text { abnormalities; decrease in } \\
\text { number of follicles. }\end{array}$ & Tualang honey & $\begin{array}{l}\text { Reduced morphological } \\
\text { abnormalities in the ovary; } \\
\text { restoration of the } \\
\text { gonadotropin hormones; } \\
\text { reduction in lipid } \\
\text { peroxidation levels; } \\
\text { increased levels of } \\
\text { antioxidant enzymes. }\end{array}$ & $\begin{array}{l}\text { Ruslee et al., } \\
2020 \text { [86] }\end{array}$ \\
\hline $\begin{array}{c}5 \mathrm{mg} / \mathrm{kg} \text { b.w. } / \text { day } \mathrm{CdCl}_{2} \\
\text { p.o. } \\
\text { albino Wistar rats }\end{array}$ & $\begin{array}{c}\text { Decrease in viable } \\
\text { follicular cells as a result of } \\
\text { apoptosis; decreased levels } \\
\text { of FSH and LH. }\end{array}$ & Quercetin & $\begin{array}{l}\text { Beneficial effects on the } \\
\text { ovaries in cadmium induced } \\
\text { toxicity; decrease in } \\
\text { apoptosis. }\end{array}$ & $\begin{array}{c}\text { Nna et al., } 2017 \\
\text { [87] }\end{array}$ \\
\hline
\end{tabular}

\begin{tabular}{|c|c|c|c|c|}
\hline $\begin{array}{c}3 \mathrm{mg} / \mathrm{kg} \text { of feed mixture; } \\
118 \text { days } \\
\mathrm{CdCl}_{2} \\
\text { p.o. } \\
\text { Japanese quails }\end{array}$ & $\begin{array}{l}\text { Lower relative volume of } \\
\text { primary follicles; decrease } \\
\text { number of growing } \\
\text { follicles; increased relative } \\
\text { volume of atretic primary } \\
\text { and growing follicles. }\end{array}$ & $\begin{array}{c}\text { Selenium } \\
\left(\mathrm{Na}_{2} \mathrm{SeO}_{3}\right) \\
\text { Zinc }\left(\mathrm{ZnSO}_{4}\right)\end{array}$ & $\begin{array}{l}\text { Se and } \mathrm{Zn} \text { improved the } \\
\text { relative volume of primary } \\
\text { and growing follicles. }\end{array}$ & $\begin{array}{c}\text { Nad' et al., } 2007 \\
\text { [88] }\end{array}$ \\
\hline $\begin{array}{c}\text { 2.5, } 5 \text { and } 10 \mathrm{mg} / \mathrm{kg} \mathrm{b.w.} \\
\mathrm{CdCl} \\
\text { s.c. } \\
\text { CFY rats }\end{array}$ & $\begin{array}{l}\text { Reduced steroidogenesis in } \\
\text { cultured granulosa cells; } \\
\text { effects on steroid } \\
\text { biosynthesis in vitro. }\end{array}$ & $\mathrm{ZnCl}_{2}$ & $\begin{array}{l}\text { Potentiated FSH-stimulated } \\
\text { progesterone production. }\end{array}$ & $\begin{array}{c}\text { Paksy et al., } \\
1996 \text { [89] }\end{array}$ \\
\hline
\end{tabular}

In a recent experimental trial using rats, the propensities of melatonin to offset toxicity of $\mathrm{Cd}$ in ovaries have been observed [83]. The autophagy and apoptosis in ovaries resulted from $\mathrm{Cd}$-induced changes in the phosphorylation of mTOR was minimal when melatonin 
was simultaneously administered with $\mathrm{Cd}$ [83]. Adverse effects of $\mathrm{Cd}$ on cytoarchitecture of the ovaries, such as the deterioration of ovarian follicles and poor vascularization, was normalized in rats treated with Cd plus Hibiscus sabdariffa [84]. In addition to restoration of cytoarchitecture, the proliferation of follicles was observed [84].

A study of the effects of Xylopia aethiopica on ovarian histology reported severe tissue necrosis, follicular cell degeneration, atresia, and absence of new follicles in Wistar rats treated only with $\mathrm{CdCl}_{2}$ [85]. Simultaneous treatment with Xylopia aethiopica extracts increased the number of primary and secondary follicles [85]. Authors attributed the observed ameliorative effects of X. aethiopica to antioxidant properties. In another study using rats, the number of antral and atretic follicles were increased in the Cd treated only group [86]. In contrast, the number of antral and atretic follicles in the ovaries were reduced in rats treated with $\mathrm{Cd}$ and Tualang honey, thereby suggesting protective effects of Tualang honey [86].

Likewise, the propensities of quercetin to offset ovarian toxicity of $\mathrm{Cd}$ have been noted [86]. In the Cd plus quercetin treated group, the structure of ovaries, the number of follicles, Graafian follicles, and the presence of follicles in various stages of development were comparable to controls [87]. Effects of Se and $\mathrm{Zn}$ on Cd-induced changes in the structure of ovaries have been investigated in Japanese quails [88]. The number of follicles undergoing atresia in the group treated only with Cd was significantly increased, evident from higher numbers of atretic primary and growing follicles, compared with groups treated with Cd plus Se and Zn. In an early study, the propensities of Zn to offset $\mathrm{Cd}$-induced sterility were investigated, and $\mathrm{Cd}$ was found to suppress progesterone accumulation stimulated by the follicle-stimulating hormone and cAMP [89]. Co-treatment of $\mathrm{Cd}$ with $\mathrm{Zn}$ protected against $\mathrm{Cd}$-induced sterility in vivo, but it failed to counteract an effect of $\mathrm{Cd}$ on progesterone biosynthesis [89].

\section{Experimental Trials to Mitigate Testicular Toxicity}

Notable effects of $\mathrm{Cd}$ on testicular tissue architecture include degeneration of the seminiferous tubules with absence of germ cells and vacuolization of the seminiferous epithelium $[16,90,91]$. Table 5 summarizes studies in which various natural substances, chemicals, and nutritionally essential metals were tested for their propensities to reduce toxic effects of $\mathrm{Cd}$ accumulation in testes.

Table 5. Experimental ameliorating testicular cadmium toxicities.

\begin{tabular}{|c|c|c|c|c|}
\hline $\begin{array}{c}\text { Cadmium } \\
\text { Dose/Form/Species }\end{array}$ & Toxic Signs & Substance & Beneficial Effects & References \\
\hline $\begin{array}{c}140 \mathrm{mg} / \mathrm{kg} \mathrm{CdCl} 2 \\
\text { p.o. } \\
\text { chicken }\end{array}$ & $\begin{array}{l}\text { Deformed seminiferous } \\
\text { tubules; mild lesions. }\end{array}$ & $\begin{array}{l}\text { Ganoderma } \\
\text { Triterpenoids }\end{array}$ & $\begin{array}{l}\text { Enhanced activity of } \\
\text { antioxidant enzymes; } \\
\text { reduced MDA content and } \\
\text { inflammatory cytokines; } \\
\text { reduced damage to testicular } \\
\text { morphology. }\end{array}$ & $\begin{array}{l}\text { Wang et al., } \\
2018 \text { [92] }\end{array}$ \\
\hline $\begin{array}{l}1 \mathrm{mg} / \mathrm{kg} \mathrm{CdCl} 2 \\
\text { i.p. } \\
\text { Kunming mice }\end{array}$ & $\begin{array}{l}\text { Pathological lesion in testis; } \\
\text { reduced supporting cells and } \\
\text { greatly decreased number of } \\
\text { spermatozoa in the lumen. }\end{array}$ & Betulinic acid & $\begin{array}{l}\text { Reduced residual levels of } \\
\text { cadmium in } \\
\text { organs-promotion of } \\
\text { cadmium excretion; } \\
\text { inhibition of apoptosis. }\end{array}$ & $\begin{array}{c}\text { Fan et al., } 2018 \\
\text { [93] }\end{array}$ \\
\hline $\begin{array}{c}1 \mathrm{mg} / \mathrm{kg} \text { b.w. } / \text { day } \\
\text { i.p. } \\
\text { Wistar rats }\end{array}$ & $\begin{array}{l}\text { Decrease in spermatozoa } \\
\text { count, morphology, motility; } \\
\text { degenerative changes in the } \\
\text { seminiferous tubule - loss of } \\
\text { spermatogenesis; severe } \\
\text { necrosis of seminiferous } \\
\text { tubules; absence of } \\
\text { spermatogenic cells. }\end{array}$ & $\mathrm{ZnCl}_{2}, \mathrm{MgCl}_{2}$ & $\begin{array}{l}\text { Spermatozoa observed in } \\
\text { seminiferous tubules; lower } \\
\text { severity of necrosis; } \mathrm{Mg} \\
\text { administration significantly } \\
\text { reduced Cd effects on } \\
\text { spermatozoa quality (at high } \\
\text { doses). }\end{array}$ & $\begin{array}{c}\text { Babaknejad } \\
\text { et al., } 2018 \text { [94] }\end{array}$ \\
\hline
\end{tabular}


Table 5. Cont.

\begin{tabular}{|c|c|c|c|c|}
\hline $\begin{array}{c}\text { Cadmium } \\
\text { Dose/Form/Species }\end{array}$ & Toxic Signs & Substance & Beneficial Effects & References \\
\hline $\begin{array}{c}30 \mathrm{mg} / \mathrm{L} ; 90 \text { days } \\
\text { p.o. } \\
\text { Wistar rats }\end{array}$ & $\begin{array}{c}\text { Reduced seminiferous } \\
\text { epithelium; decreased tubular } \\
\text { lumen; increased vascular } \\
\text { surface area and vascular } \\
\text { volume. }\end{array}$ & Diazinon & $\begin{array}{l}\text { Combined administration } \\
\text { produced fewer pathological } \\
\text { alterations in testes than } \\
\text { single cadmium } \\
\text { administration. }\end{array}$ & $\begin{array}{l}\text { Adamkovicova } \\
\text { et al., } 2014 \text { [95] }\end{array}$ \\
\hline
\end{tabular}

A protective effect of Ganoderma triterpenoids on testicular damage by Cd was investigated in chickens [92]. In histological examination, deformation of the seminiferous tubules in the testes was observed together with germ cells shedding into the lumen in the Cd-treated group. The activities of glutathione peroxidase (GSH-Px) and superoxide dismutase (SOD) in the testes of the Cd group were decreased. In the group co-treated with Ganoderma triterpenoids, mild lesions were seen [92]. A study in Kunming mice suggested that betulinic acid may lessen pathological lesions in testes, namely abnormal morphology, reduced supporting cells, decreased number of spermatozoa in the lumen, caused by $\mathrm{Cd}$ [93]. Another study in rats suggested that $\mathrm{Zn}$ and magnesium $(\mathrm{Mg}$ ) may decrease testicular weight loss and the necrosis of seminiferous tubules that were induced by $\mathrm{Cd}$ [94]. Effects of diazinon on testicular $\mathrm{Cd}$ toxicity have been investigated in rats under sub-chronic exposure conditions that resulted in moderate to severe testicular degeneration and distortion due to lumen contraction [94]. These changes were less pronounced in rats given both $\mathrm{Cd}$ and diazinon as were the disorganization and degeneration of seminiferous epithelium [95].

\section{Conclusions}

Low environmental exposure to $\mathrm{Cd}$ does produce detrimental effects on the functions of female and male gonads, including sex hormone production and gametogenesis. Premature ovarian failure observed in studies of women in the U.S., China and Korea has been linked to deranged serum concentrations of testosterone, estradiol, FSH, LH, and AMH associated with environmental $\mathrm{Cd}$ exposure. These data may represent an effect of $\mathrm{Cd}$ on the hypothalamic-pituitary-gonadal axis. A fall of sperm concentration, total sperm count, and spermatozoa motility have been observed in studies of Chinese and Italian men, while protective effects of $\mathrm{Zn}$ and Se have been noted. The toxicities of $\mathrm{Cd}$ in gonads have been detectable at low body burden, reflected by $\mathrm{E}_{\mathrm{Cd}}$ below $1 \mu \mathrm{g} / \mathrm{g}$ creatinine. Thus, a greater effort needs to be made to reduce dietary intake of $\mathrm{Cd}$. Long-term management of $\mathrm{Cd}$ in the environment and agricultural produce is required to minimize the food-chain transfer of $\mathrm{Cd}$, notably from use of phosphate fertilizers. Avoidance of further soil Cd contamination needs much more awareness of $\mathrm{Cd}$ levels in phosphate fertilizers, mining waste and wastewater. The persistence of $\mathrm{Cd}$ in the environment requires a long-term management approach to minimization of human exposure through environmental management and maintenance of the lowest possible $\mathrm{Cd}$ level, wherever possible.

In numerous experimental studies, reported effects of $\mathrm{Cd}$ in ovaries include decreased follicular growth, follicular atresia, and prolonged estrus cycle, while disorganization of germinal epithelium in seminiferous tubules and abnormal spermatogenesis are notable $\mathrm{Cd}$ effects in testes. Some of the ovarian $\mathrm{Cd}$ toxicities could be ameliorated by Hibiscus sabdariffa, Costus afer leaves, Ganoderma triterpenoids, Betulinic acid, Zn, Mg, Xylopia aethiopica, Tualang honey, melatonin, quercetin, and selenium. Costus afer leaves, Ganoderma triterpenoids, betulinic acid, $\mathrm{Zn}$ and $\mathrm{Mg}$ showed the propensities to reduce $\mathrm{Cd}$ toxicities in testes. In the absence of therapeutically effective chelating agents for lowering body burden of $\mathrm{Cd}$, these substances may be of use in the mitigation of $\mathrm{Cd}$ toxicity. Further research is required to demonstrate suitable dose regime and efficacy. 


\begin{abstract}
Author Contributions: Conceptualization, M.M., S.S., R.M., R.S. and P.M.; methodology, M.M., S.S., and P.M.; writing - original draft preparation, M.M., S.S, R.S. and P.M.; review and editing, S.S. and P.M.; supervision, S.S., P.M. and R.S. All authors have read and agreed to the published version of the manuscript.
\end{abstract}

Funding: This work was made possible by the Scientific Grant Agency of the Ministry of Education, Science, Research and Sport of the Slovak Republic (VEGA1/0539/18) and the Slovak Research and Development Agency (APVV-16-0289). Additional support was from the Operational program Integrated Infrastructure within the project: Demand-driven research for the sustainable and innovative food, Drive4SIFood 313011V336, financed by the European Regional Development Fund.

Acknowledgments: Authors prepared this review in relation to their activities in the International Society for Research on Cadmium and Trace Element Toxicity (M.M., S.S., R.M., P.M.), and CeRA research team at SUA in Nitra (P.M.).

Conflicts of Interest: The authors declare no conflict of interest.

\title{
References
}

1. Agency for Toxic Substances and Disease Registry (ATSDR). Toxicological Profile for Cadmium; Department of Health and Humans Services, Public Health Service, Centers for Disease Control and Prevention: Atlanta, GA, USA, 2012.

2. WHO. IPCS (International Programme on Chemical Safety) Environmental Health Criteria 134: Cadmium; WHO: Geneva, Switzerland, 1992.

3. Järup, L. Hazards of heavy metal contamination. Br. Med. Bull. 2003, 68, 167-182. [CrossRef]

4. Garrett, R.G. Natural sources of metals to the environment. Hum. Ecol. Risk Assess. 2010, 6, 945-963. [CrossRef]

5. Satarug, S.; Phelps, K.R. Cadmium Exposure and Toxicity. In Metal Toxicology Handbook; Bagchi, D., Bagchi, M., Eds.; CRC Press: Boca Raton, FL, USA, 2021; pp. 219-274.

6. Lamb, D.T.; Kader, M.; Ming, H.; Wang, L.; Abbasi, S.; Megharaj, M.; Naidu, R. Predicting plant uptake of cadmium: Validated with long-term contaminated soils. Ecotoxicology 2016, 25, 1563-1574. [CrossRef] [PubMed]

7. Satarug, S.; Vesey, D.A.; Gobe, G.C. Current health risk assessment practice for dietary cadmium: Data from different countries. Food Chem. Toxicol. 2017, 106, 430-445. [CrossRef]

8. Satarug, S. Dietary cadmium intake and its effects on kidneys. Toxics 2018, 6, 15. [CrossRef] [PubMed]

9. Capcarová, M.; Harangozó, L.; Árvay, J.; Tóth, T.; Gabriny, L.; Binkowski, L.J.; Palšová, L.; Skalická, M.; Pardo, M.L.G.; Stawarz, R.; et al. Essential and xenobiotic elements in cottage cheese from the Slovak market with a consumer risk assessment. J. Environ. Sci. Health B. 2020, 55, 677-686. [CrossRef] [PubMed]

10. Wu, S.; Deng, F.; Hao, Y.; Shima, M.; Wang, X.; Zheng, C.; Wei, H.; Lv, H.; Lu, X.; Huang, J.; et al. Chemical constituents of fine particulate air pollution and pulmonary function in healthy adults: The healthy volunteer natural relocation study. J. Hazard. Mater. 2013, 260, 183-191. [CrossRef] [PubMed]

11. Jung, M.S.; Kim, J.Y.; Lee, H.S.; Lee, C.G.; Song, H.S. Air pollution and urinary N-acetyl- $\beta$-glucosaminidase levels in residents living near a cement plant. Ann. Occup. Environ. Med. 2016, 28, 52. [CrossRef]

12. Jin, Y.; Lu, Y.; Li, Y.; Zhao, H.; Wang, X.; Shen, Y.; Kuang, X. Correlation between environmental low-dose cadmium exposure and early kidney damage: A comparative study in an industrial zone vs. a living quarter in Shanghai, China. Environ. Toxicol. Pharmacol. 2020, 79, 103381. [CrossRef] [PubMed]

13. Repić, A.; Bulat, P.; Antonijević, B.; Antunović, M.; Džudović, J.; Buha, A.; Bulat, Z. The influence of smoking habits on cadmium and lead blood levels in the Serbian adult people. Environ. Sci. Pollut. Res. Int. 2020, 27, 751-760. [CrossRef] [PubMed]

14. Pappas, R.S.; Fresquez, M.R.; Watson, C.H. Cigarette smoke cadmium breakthrough from traditional filters: Implications for exposure. J. Anal. Toxicol. 2015, 39, 45-51. [CrossRef]

15. Satarug, S.; Vesey, D.A.; Gobe, G.C. Health risk assessment of dietary cadmium intake: Do current guidelines indicate how much is safe? Environ. Health Perspect. 2017, 125, 284-288. [CrossRef] [PubMed]

16. Massányi, P.; Massányi, M.; Madeddu, R.; Stawarz, R.; Lukáč, N. Effects of Cadmium, Lead, and Mercury on the Structure and Function of Reproductive Organs. Toxics 2020, 8, 94. [CrossRef] [PubMed]

17. Tirpák, F.; Halo, M., Jr.; Tokárová, K.; Binkowski, L.J.; Vaščček, J.; Svoradová, A.; Błaszczyk-Altman, M.; Kováčik, A.; Tvrdá, E.; Chrenek, P.; et al. Composition of Stallion Seminal Plasma and Its Impact on Oxidative Stress Markers and Spermatozoa Quality. Life 2021, 11, 1238. [CrossRef] [PubMed]

18. Peana, M.; Pelucelli, A.; Medici, S.; Cappai, R.; Nurchi, V.M.; Zoroddu, M.A. Metal Toxicity and Speciation: A review. Curr. Med. Chem. 2021, 28, 7190-7208. [CrossRef] [PubMed]

19. Khan, W.A.; Arain, M.B.; Soylak, M. Nanomaterials-based solid phase extraction and solid phase microextraction for heavy metals food toxicity. Food Chem. Toxicol. 2020, 145, 111704. [CrossRef]

20. Rana, M.N.; Tangpong, J.; Rahman, M.M. Toxicodynamics of lead, cadmium, mercury and arsenic-induced kidney toxicity and treatment strategy: A mini review. Toxicol. Rep. 2018, 26, 704-713. [CrossRef] 
21. Zofkova, I.; Davis, M.; Blahos, J. Trace elements have beneficial, as well as detrimental effects on bone homeostasis. Physiol. Res. 2017, 66, 391-402. [CrossRef] [PubMed]

22. Scientific Opinion of the Panel on Contaminants in the Food Chain on a request from the European Commission on cadmium in food. EFSA J. 2009, 980, 1-139.

23. Kim, K.; Melough, M.M.; Vance, T.M.; Noh, H.; Koo, S.I.; Chun, O.K. Dietary cadmium intake and sources in the US. Nutrients 2018, 11, 2. [CrossRef] [PubMed]

24. Marín, S.; Pardo, O.; Báguena, R.; Font, G.; Yusà, V. Dietary exposure to trace elements and health risk assessment in the region of Valencia, Spain: A total diet study. Food Addit. Contam. Part A Chem. Anal. Control Expo. Risk Assess. 2017, 34, 228-240. [CrossRef] [PubMed]

25. Vromman, V.; Waegeneers, N.; Cornelis, C.; De Boosere, I.; Van Holderbeke, M.; Vinkx, C.; Smolders, E.; Huyghebaert, A.; Pussemier, L. Dietary cadmium intake by the Belgian adult population. Food Addit. Contam. Part A Chem. Anal. Control Expo. Risk Assess. 2010, 27, 1665-1673. [CrossRef]

26. Sand, S.; Becker, W. Assessment of dietary cadmium exposure in Sweden and population health concern including scenario analysis. Food Chem. Toxicol. 2012, 50, 536-544. [CrossRef] [PubMed]

27. Arnich, N.; Sirot, V.; Rivière, G.; Jean, J.; Noël, L.; Guérin, T.; Leblanc, J.-C. Dietary exposure to trace elements and health risk assessment in the 2nd French Total Diet Study. Food Chem. Toxicol. 2012, 50, 2432-2449. [CrossRef] [PubMed]

28. Lim, J.A.; Kwon, H.J.; Ha, M.; Kim, H.; Oh, S.Y.; Kim, J.S.; Lee, S.A.; Park, J.D.; Hong, Y.S.; Sohn, S.J.; et al. Korean research project on the integrated exposure assessment of hazardous substances for food safety. Environ. Health Toxicol. 2015, 30, e2015004. [CrossRef] [PubMed]

29. Schwarz, M.A.; Lindtner, O.; Blume, K.; Heinemeyer, G.; Schneider, K. Cadmium exposure from food: The German LExUKon project. Food Addit. Contam. Part A Chem. Anal. Control Expo. Risk Assess. 2014, 31, 1038-1051. [CrossRef]

30. Wei, J.; Gao, J.; Cen, K. Levels of eight heavy metals and health risk assessment considering food consumption by China's residents based on the 5th China total diet study. Sci. Total Environ. 2019, 689, 1141-1148. [CrossRef]

31. Horiguchi, H.; Oguma, E.; Sasaki, S.; Miyamoto, K.; Hosoi, Y.; Ono, A.; Kayama, F. Exposure assessment of cadmium in female farmers in cadmium-polluted areas in Northern Japan. Toxics 2020, 8, 44. [CrossRef] [PubMed]

32. Varga, B.; Zsolnai, B.; Paksy, K.; Náray, M.; Ungváry, G. Age dependent accumulation of cadmium in the human ovary. Reprod. Toxicol. 1993, 7, 225-228. [CrossRef]

33. Oldereid, N.B.; Thomassen, Y.; Attramadal, A.; Olaisen, B.; Purvis, K. Concentrations of lead, cadmium and zinc in the tissues of reproductive organs of men. J. Reprod. Fertil. 1993, 99, 421-425. [CrossRef]

34. Oldereid, N.B.; Thomassen, Y.; Purvis, K. Selenium in human male reproductive organs. Hum. Reprod. 1998, 13, 2172-2176. [CrossRef] [PubMed]

35. Sapra, K.J.; Barr, D.B.; Maisog, J.M.; Sundaram, R.; Louis, G.M.B. Time-to-pregnancy associated with couples' use of tobacco products. Nicotine Tob. Res. 2016, 18, 2154-2161. [CrossRef] [PubMed]

36. Crinnion, W.J. The CDC fourth national report on human exposure to environmental chemicals: What it tells us about our toxic burden and how it assists environmental medicine physicians. Altern. Med. Rev. 2010, 15, 101-108.

37. Scott, B.J.; Bradwell, A.R. Identification of the serum binding proteins for iron, zinc, cadmium, nickel, and calcium. Clin. Chem. 1983, 29, 629-633. [CrossRef] [PubMed]

38. Horn, N.M.; Thomas, A.L. Interactions between the histidine stimulation of cadmium and zinc influx into human erythrocytes. J. Physiol. 1996, 496, 711-718. [CrossRef] [PubMed]

39. Sagmeister, P.; Gibson, M.A.; McDade, K.H.; Gailer, J. Physiologically relevant plasma d,l-homocysteine concentrations mobilize Cd from human serum albumin. J. Chromatogr. B Anal. Technol. Biomed. Life Sci. 2016, 1027, 181-186. [CrossRef]

40. Rokadia, H.K.; Agarwal, S. Serum heavy metals and obstructive lung disease: Results from the National Health and Nutrition Examination Survey. Chest 2013, 143, 388-397. [CrossRef]

41. Yang, G.; Sun, T.; Han, Y.Y.; Rosser, F.; Forno, E.; Chen, W.; Celedón, J.C. Serum cadmium and lead, current wheeze, and lung function in a nationwide study of adults in the United States. J. Allergy Clin. Immunol. Pract. 2019, 7, 2653-2660.e3. [CrossRef]

42. Kaneda, M.; Wai, K.M.; Kanda, A.; Ando, M.; Murashita, K.; Nakaji, S.; Ihara, K. Low level of serum cadmium in relation to blood pressures among Japanese general population. Biol. Trace Elem. Res. 2022, 200, 67-75. [CrossRef]

43. Lee, S.; Min, J.Y.; Min, K.B. Female infertility associated with blood lead and cadmium levels. Int. J. Environ. Res. Public Health 2020, 17, 1794. [CrossRef] [PubMed]

44. Jackson, L.W.; Zullo, M.D.; Goldberg, J.M. The association between heavy metals, endometriosis and uterine myomas among premenopausal women: National Health and Nutrition Examination Survey 1999-2002. Hum. Reprod. 2008, 23, 679-687. [CrossRef]

45. Kim, K.; Pollack, A.Z.; Nobles, C.J.; Sjaarda, L.A.; Zolton, J.R.; Radoc, J.G.; Schisterman, E.F.; Mumford, S.L. Associations between blood cadmium and endocrine features related to PCOS-phenotypes in healthy women of reproductive age: A prospective cohort study. Environ. Health 2021, 20, 64. [CrossRef]

46. Upson, K.; O’Brien, K.M.; Hall, J.E.; Tokar, E.J.; Baird, D.D. Cadmium exposure and ovarian reserve in women aged 35-49 years: The impact on results from the creatinine adjustment approach used to correct for urinary dilution. Am. J. Epidemiol. 2021, 190, 116-124. [CrossRef] [PubMed] 
47. Pan, W.; Ye, X.; Zhu, Z.; Li, C.; Zhou, J.; Liu, J. Urinary cadmium concentrations and risk of primary ovarian insufficiency in women: A case-control study. Environ. Geochem. Health 2021, 43, 2025-2035. [CrossRef] [PubMed]

48. Lee, Y.M.; Chung, H.W.; Jeong, K.; Sung, Y.A.; Lee, H.; Ye, S.; Ha, E.H. Association between cadmium and anti-Mullerian hormone in premenopausal women at particular ages. Ann. Occup. Environ. Med. 2018, 30, 44. [CrossRef] [PubMed]

49. World Health Organization. WHO Manual for the Examination and Processing of Human Semen, 5th ed.; WHO: Geneva, Switzerland; Cambridge University Press: Cambridge, UK, 2010; pp. 4-33.

50. Kumar, N.; Singh, A.K. Trends of male factor infertility, an important cause of infertility: A review of literature. J. Hum. Reprod. Sci. 2015, 8, 191-196. [CrossRef]

51. Jeng, H.A.; Huang, Y.-L.; Pan, C.-H.; Norou Diawara, N. Role of low exposure to metals as male reproductive toxicants. Int. J. Environ. Health Res. 2015, 25, 405-417. [CrossRef]

52. Calogero, A.E.; Fiore, M.; Giacone, F.; Altomare, M.; Asero, P.; Ledda, C.; Romeo, G.; Mongioì, L.M.; Copat, C.; Giuffrida, M.; et al Exposure to multiple metals/metalloids and human semen quality: A cross-sectional study. Ecotoxicol. Environ. Saf. 2021, 215, 112165. [CrossRef] [PubMed]

53. Wang, Y.X.; Wang, P.; Feng, W.; Liu, C.; Yang, P.; Chen, Y.J.; Sun, L.; Sun, Y.; Yue, J.; Gu, L.J.; et al. Relationships between seminal plasma metals/metalloids and semen quality, sperm apoptosis and DNA integrity. Environ. Pollut. 2017, 224, 224-234. [CrossRef]

54. Nsonwu-Anyanwu, A.C.; Ekong, E.R.; Offor, S.J.; Awusha, Q.F.; Orji, O.C.; Umoh, E.I.; Owhorji, J.A.; Emetonjor, F.R.; Usoro, C.A.O. Heavy metals, biomarkers of oxidative stress and changes in sperm function: A case-control study. Int. J. Reprod. Biomed. 2019, 17, 163-174. [CrossRef]

55. Mendiola, J.; Moreno, J.M.; Roca, M.; Vergara-Juárez, N.; Martínez-García, M.J.; García-Sánchez, A.; Elvira-Rendueles, B.; MorenoGrau, S.; López-Espín, J.J.; Ten, J.; et al. Relationships between heavy metal concentrations in three different body fluids and male reproductive parameters: A pilot study. Environ. Health 2011, 10, 6. [CrossRef] [PubMed]

56. Pant, N.; Kumar, G.; Upadhyay, A.D.; Gupta, Y.K.; Chaturvedi, P.K. Correlation between lead and cadmium concentration and semen quality. Andrologia 2015, 47, 887-891. [CrossRef] [PubMed]

57. Inoue, K.; Takano, H.; Shimada, A.; Satoh, M. Metallothionein as an anti-inflammatory mediator. Mediators Inflamm. 2009, 101659. [CrossRef] [PubMed]

58. Genchi, G.; Sinicropi, M.S.; Lauria, G.; Carocci, A.; Catalano, A. The Effects of Cadmium Toxicity. Int. J. Environ. Res. Public Health 2020, 17, 3782. [CrossRef] [PubMed]

59. Sato, S.; Okabe, M.; Kurasaki, M.; Kojima, Y. Metallothionein in the ovaries of laying hens exposed to cadmium. Life Sci. 1996, 58, 1561-1567. [CrossRef]

60. Foulkes, E.C. Cadmium. In Handbook of Experimental Pharmacology; Springer: Berlin/Heidelberg, Germany, 1986; pp. 1-400.

61. Jarup, L.; Berglund, M.; Elinder, C.G.; Nordberg, G.; Vahter, M. Health effects of cadmium exposure-A review of the literature and a risk estimate. Scand. J. Work Environ. Health 1998, 24, 1-51. [PubMed]

62. Prozialeck, W. New insights into the mechanisms of cadmium toxicity-advances in cadmium research. Toxicol. Appl. Pharmacol. 2009, 238, 1-326. [CrossRef] [PubMed]

63. Moulis, J.-M.; Thevenod, F. New perspectives in cadmium toxicity. BioMetals 2010, 23, 763-960. [CrossRef]

64. Waalkes, M.P.; Rehm, S.; Peratoni, A. Metal-Binding Proteins of the Syrian Hamster Ovaries: Apparent Deficiency of Metallothionein. Biol. Reprod. 1988, 39, 953-961. [CrossRef]

65. Rani, A.; Kumar, A.; Lal, A.; Pant, M. Cellular mechanisms of cadmium-induced toxicity: A review. Int. J. Environ. Health Res. 2014, 24, 378-399. [CrossRef]

66. Satarug, S.; Moore, M.R. Adverse health effects of chronic exposure to low-level cadmium in foodstuffs and cigarette smoke. Environ. Health Perspect. 2004, 112, 1099-1103. [CrossRef]

67. Satarug, S.; Garrett, S.H.; Somji, S.; Sens, M.A.; Sens, D.A. Zinc, zinc transporters, and cadmium cytotoxicity in a cell culture model of human urothelium. Toxics 2021, 9, 94. [CrossRef]

68. Satarug, S.; Garrett, S.H.; Somji, S.; Sens, M.A.; Sens, D.A. Aberrant expression of ZIP and ZnT zinc transporters in UROtsa cells transformed to malignant cells by cadmium. Stresses 2021, 1, 78-89. [CrossRef]

69. Satarug, S.; Vesey, D.A.; Gobe, G.C. The evolving role for zinc and zinc transporters in cadmium tolerance and urothelial cancer. Stresses 2021, 1, 105-118. [CrossRef]

70. Wang, B.; Schneider, S.N.; Dragin, N.; Girijashanker, K.; Dalton, T.P.; He, L.; Miller, M.L.; Stringer, K.F.; Soleimani, M.; Richardson, D.D.; et al. Enhanced cadmium-induced testicular necrosis and renal proximal tubule damage caused by gene-dose increase in a Slc39a8-transgenic mouse line. Am. J. Physiol. Cell Physiol. 2007, 292, C1523-C1535. [CrossRef]

71. He, L.; Wang, B.; Hay, E.B.; Nebert, D.W. Discovery of ZIP transporters that participate in cadmium damage to testis and kidney. Toxicol. Appl. Pharmacol. 2009, 238, 250-257. [CrossRef] [PubMed]

72. Cheng, C.Y.; Mruk, D.D. The blood-testis barrier and its implications for male contraception. Pharmacol. Rev. 2012, 64, 16-64. [CrossRef] [PubMed]

73. Schieber, M.; Chandel, N.S. ROS function in redox signaling and oxidative stress. Curr. Biol. 2014, 24, R453-R462. [CrossRef]

74. He, L.; He, T.; Farrar, S.; Ji, L.; Liu, T.; Ma, X. Antioxidants Maintain Cellular Redox Homeostasis by Elimination of Reactive Oxygen Species. Cell Physiol. Biochem. 2017, 44, 532-553. [CrossRef] [PubMed]

75. Tvrdá, E.; Kňažická, Z.; Bárdos, L.; Massányi, P.; Lukáč, N. Impact of oxidative stress on male fertility-A review. Acta Vet. Hung. 2011, 59, 465-484. [CrossRef] 
76. Xu, G.; Liu, S.; Huang, M.; Jiang, X.; Yang, M. Cadmium induces apoptosis of human granulosa cell line KGN via mitochondrial dysfunction-mediated pathways. Ecotoxicol. Environ. Saf. 2021, 220, 112341. [CrossRef]

77. Nishi, Y.; Yanase, T.; Mu, Y.; Oba, K.; Ichino, I.; Saito, M.; Nomura, M.; Mukasa, C.; Okabe, T.; Goto, K.; et al. Establishment and characterization of a steroidogenic human granulosa-like tumor cell line, KGN, that expresses functional follicle-stimulating hormone receptor. Endocrinology 2001, 142, 437-445. [CrossRef] [PubMed]

78. Zhang, Q.; Zou, P.; Zhan, H.; Zhang, M.; Zhang, L.; Ge, R.-S.; Huang, Y. Dihydrolipoamide dehydrogenase and cAMP are associated with cadmium-mediated Leydig cell damage. Toxicol. Lett. 2011, 205, 183-189. [CrossRef] [PubMed]

79. Ji, X.; Li, Z.; Chen, H.; Li, J.; Tian, H.; Li, Z.; Gao, X.; Xiang, Q.; Su, Z.; Huang, Y.; et al. Cytotoxic mechanism related to dihydrolipoamide dehydrogenase in Leydig cells exposed to heavy metals. Toxicology 2015, 334, 22-32. [CrossRef] [PubMed]

80. Wu, X.; Guo, X.; Wang, H.; Zhou, S.; Li, L.; Chen, X.; Wang, G.; Liu, J.; Ge, H.-S.; Ge, R.-S. A brief exposure to cadmium impairs Leydig cell regeneration in the adult rat testis. Sci. Rep. 2017, 207, 6337. [CrossRef]

81. Zeng, L.; Zhou, J.; Wang, X.; Zhang, Y.; Wang, M.; Su, P. Cadmium attenuates testosterone synthesis by promoting ferroptosis and blocking autophagosome-lysosome fusion. Free Radic. Biol. Med. 2021, 176, 176-188. [CrossRef] [PubMed]

82. Zhou, G.X.; Zhu, H.L.; Shi, X.T.; Nan, Y.; Liu, W.B.; Dai, L.M.; Xiong, Y.-W.; Yi, S.-J.; Cao, X.-L.; Xu, D.-X.; et al. Autophagy in Sertoli cell protects against environmental cadmium-induced germ cell apoptosis in mouse testes. Environ. Pollut. 2021, 270, 116241. [CrossRef] [PubMed]

83. Kechiche, S.; Venditti, M.; Knani, L.; Jablonska, K.; Dziegiel, P.; Messaoudi, I.; Reiter, R.J.; Minucci, S. First evidence of the protective role of melatonin in counteracting cadmium toxicity in the rat ovary via the mTOR pathway. Environ. Pollut. 2021, 270, 116056. [CrossRef] [PubMed]

84. Oyewopo, A.O.; Olaniyi, K.S.; Olojede, S.O.; Lawal, S.K.; Amusa, O.A.; Ajadi, I.O. Hibiscus sabdariffa extract protects against cadmium-induced ovarian toxicity in adult Wistar rats. Int. J. Patophysiol. Pharmacol. 2020, 12, 107-114.

85. Godam, E.T.; Olaniyan, O.T.; Wofuru, C.D.; Orupabo, C.D.; Ordu, K.S.; Gbaranor, B.K.; Dakoru, P.D. Xylopia aethiopica ethanol seed extract suppresses cadmium chloride-induced ovary and gonadotropins toxicity in adults female Wistar rats. JBRA Assist. Reprod. 2021, 27, 252-256. [CrossRef]

86. Ruslee, S.S.; Zaid, S.S.; Bakrin, I.H.; Goh, Y.M.; Mustapha, N.M. Protective effect of Tualang honey against cadmium-induced morphological abnormalities and oxidative stress in the ovary of rats. BMC Complement. Med. Ther. 2020, 20, 160. [CrossRef] [PubMed]

87. Nna, V.U.; Usman, U.Z.; Ofutet, E.O.; Owu, D.U. Quercetin exerts preventive, ameliorative and prophylactic effects on cadmium chloride-induced oxidative stress in the uterus and ovaries of female Wistar rats. Food Chem. Toxicol. 2017, 102, 143-155.

88. Nad', P.; Massányi, P.; Skalická, M.; Koréneková, B.; Cigánková, V.; Almásiová, V. The effect of cadmium in combination with zinc and selenium on ovarian structure in Japanese quails. J. Environ. Sci. Health A 2007, 42, 2017-2022. [CrossRef] [PubMed]

89. Paksy, K.; Varga, B.; Lazar, P. Zinc protection against cadmium-induced infertility in female rats. Effect of zinc and cadmium on the progesterone production of cultured granulosa cells. Biometals 1997, 10, 27-36. [CrossRef] [PubMed]

90. Tirpák, F.; Greifová, H.; Lukáč, N.; Stawarz, R.; Massányi, P. Exogenous Factors Affecting the Functional Integrity of Male Reproduction. Life 2021, 11, 213. [CrossRef] [PubMed]

91. Mouro, V.G.S.; Martins, A.L.P.; Silva, J.; Menezes, T.P.; Gomes, M.L.M.; Oliveira, J.A.; Melo, F.C.S.A.; Matta, S.L.P. Subacute Testicular Toxicity to Cadmium Exposure Intraperitoneally and Orally. Oxid. Med. Cell. Longev. 2019, 2019, 3429635. [CrossRef]

92. Wang, H.; Zhang, R.; Song, Y.; Li, T.; Ge, M. Protective Effect of Ganoderma Triterpenoids on Cadmium-Induced Testicular Toxicity in Chickens. Biol. Trace Elem. Res. 2019, 187, 281-290. [CrossRef]

93. Fan, R.; Hu, P.-C.; Wang, Y.; Lin, H.-Y.; Su, K.; Feng, X.-S.; Wei, L.; Yang, F. Betulinic acid protects mice from cadmium chloride-induced apoptosis in kidney and liver. Toxicol. Lett. 2018, 299, 56-66. [CrossRef]

94. Babaknejad, N.; Bah\&rami, S.; Moshtaghie, S.A.A.; Nayeri, H.; Rajabi, P.; Iranpour, F.G. Cadmium Testicular Toxicity in Male Wistar Rats: Preventive Role of Zinc and Magnesium. Biol. Trace Elem. Res. 2018, 185, 106-115. [CrossRef] [PubMed]

95. Adamkovičová, M.; Toman, R.; Cabaj, M.; Massányi, P.; Martiniaková, M.; Omelka, R.; Krajčovicová, V.; Duránová, H. Effects of Subchronic Exposure to Cadmium and Diazinon on Testis and Epididymis in Rats. Sci. World J. 2014, 2014, 632581. [CrossRef] [PubMed] 